\title{
An Assessment of Flood Risk and Adaptation Measures in Isheri North of Ogun State, Nigeria
}

\author{
Toka, Sunday Onajomo \\ Dept. of Climate Change, Ministry of Environment and Water Resources, Lagos State, Nigeria
}

\begin{abstract}
The increasing frequency of flooding incidents in Isheri North of Ogun State is a growing concern. The overflow of the Ogun River as a result of increased volume of rainfall persistently led to flooding in communities resulting in loss of lives and properties. The study assessed the environmental and socio-economic impacts of flooding in the area. Monthly rainfall data records for 30 years (1990-2019) were obtained from Nigerian Meteorological Agency (NiMET), lkeja and analyzed using basic descriptive statistical technique. Landsat images for 2000, 2015 and 2020 with $30 \mathrm{~m}$ resolution were obtained and analyzed to determine the implications of the flooding on the inhabitants of the areas. Land uses were identified and classified from the satellite imageries help in evaluating the impacts of the floods. The data were subjected to digital image processing and supervised classification was carried out on the images of the various dates. Results obtained shows flooding has strong connection with rapid population growth and infrastructure expansion along the floodplain, inadequate setback from the river valley and unregulated urban land use. On the basis of the results, the paper suggest approaches to the challenge including: land-use planning and flood control policies including a firm control on infrastructure development.
\end{abstract}

Keywords:Flooding, Geographical information system, Land cover, Landsat Imageries

DOI: $10.7176 / \mathrm{JEES} / 11-11-02$

Publication date: November $30^{\text {th }} 2021$

\section{Introduction}

Flooding is debatably a weather-related hazard that is most pervasive globally (Oje and Ugbonna 2010: Toka 2017). It is one of the greatest devastating hazards in the world today to both humans and properties (Nwilo et al, 2011). Flooding incidences have become more frequent and severe around the world, especially in the coastal and urban areas in developing countries. This is attributable to climate change and sea-level rise, (Levermann, et al 2013) and is a major concern globally. According to t (Oyinloye et al 2013) that flood is an extreme weather event naturally caused by rising global temperature which results in a heavy downpour, thermal expansion, of the ocean and glacier melt, which in turn results in rising in sea level thereby causing saltwater to inundated coastal lands. Flooding has caused about one-third of all death and hundreds of thousands have been rendered homeless and properties worth millions of Naira destroyed as a result of the devastating flood across the country (Oyinloye et al 2013).

Flooding is becoming a perennial event and more devastating in Isheri North (Yoade et al, 2014). The 2019 was the highest flood disaster in many years. As reported by (Onwuka et al 2015) torrential rainfall lasting many hours resulted in the Ogun River overflowing its banks leading to the breakdown of the dam and a devastating flood in the area. This negatively affected the economy and business of that area. It damaged the major road link, disrupting transport network and accessibility and loss of communication network. There no analysis of the historic flood hazards in Isheri North of Lagos State. This calls for periodic study that will aid in analyses of flood event in the Study area. (Ojeh et al, 2012). Addressing this gap is what this study seek to contribute to. The purpose of the study is to assess the magnitude of flooding in the area and examine the effects of the floods on the physical and social-economic lives of the area. 
(a)

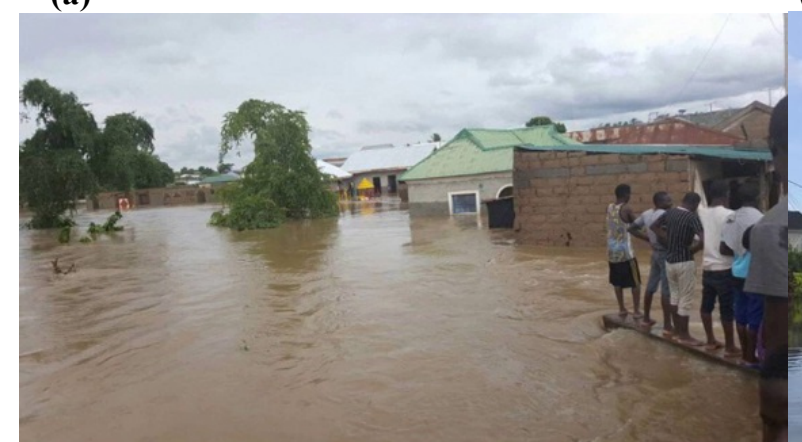

(c) (b)

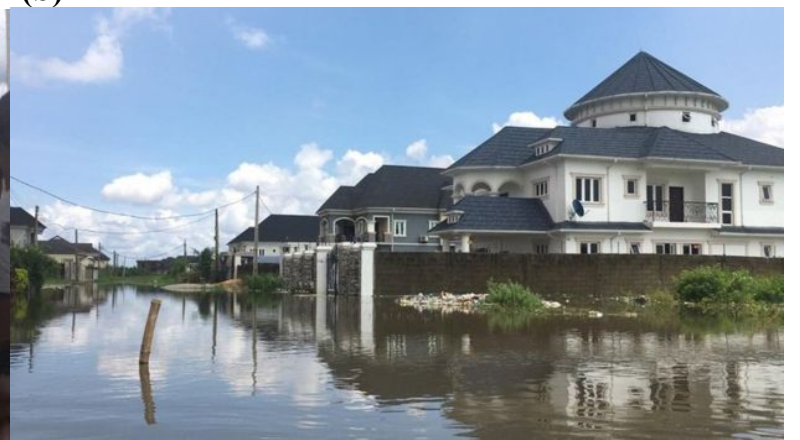

(d)

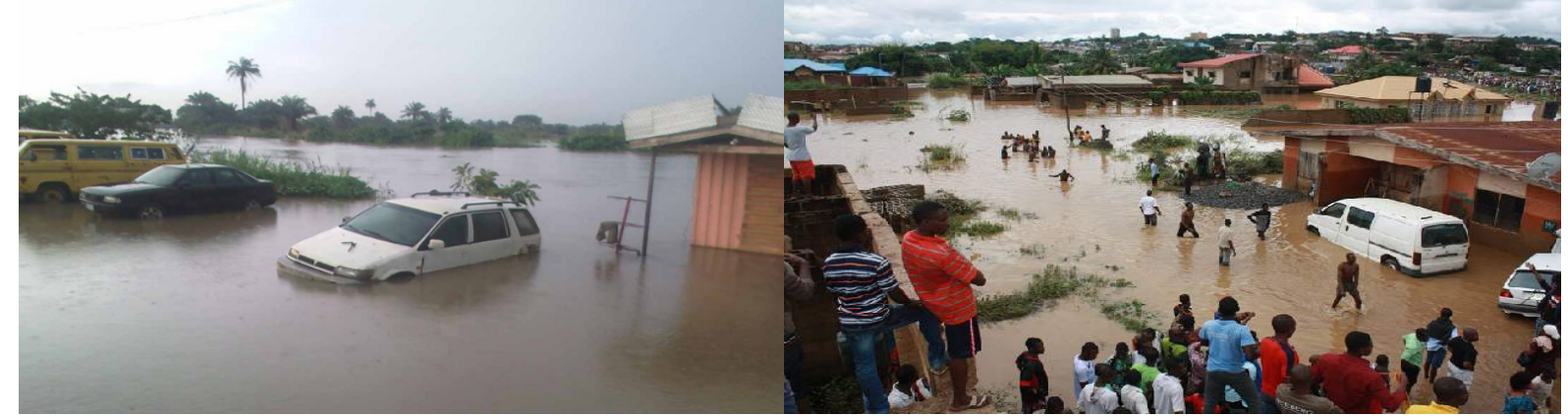

Plate 1: Selected flood events in the study area; (a) showing submerged houses during 2012 flooding in isheri, (b), inundated road 2016 in Isheri north, (c), submerged vehicles in Isheri during the 2018 (d), and inundated streets in Isheri north, Ogun, Nigeria, in 2019.

Existing flood-related studies have shown that flooding has remained a pandemic over the years, which successive government in the state could not effectively solve (Ogungbemi and Hassan, 2020), on parts of the Nigerian coastline, especially Lagos area, have focused on land use /land cover change, as well as rainfall trends and patterns, and their impact on inundation (e.g. Rilwani and Ikhuoria 2006; Salami et al. 2006; Ikhuoria et al. 2006; Salami 2006; Nuga and Akinbola 2011). A review of studies in the southwestern part of Nigeria suggests an increase in the application of remote sensing in environmental monitoring, especially for data collection and analysis, as the technology develops in the country (Oyinloye and Kufoniyi 2013; Eludoyin et al., 2019; Eludoyin and Iyanda, 2019). Many of these studies reveal a transition from the use of aerial photographs and topographical maps to satellite remote sensing data, such as SPOT and Landsat imageries as they become available for exploration by researchers in the country. Remote sensing datasets provide adequate tools to understanding the past, present and future state of land use and land cover change in an area, but except for the Landsat (Satellite Programme of the National Aeronautics and Space Administration (NASA)) imageries that are free to acquire at the NASA website, many high resolution remote sensing imageries are very expensive for most researchers and students in many developing countries, especially in Africa to procure (Omodanisi et al. 2014; Eludoyin and Iyanda, 2019).

The present study aim to assess the environmental and socio-economic impacts of flooding in the area and understanding of the causes of flooding in the region will enhance and provide additional information that can assist the government and private sector organizations to involve in managing Isheri north environment to combat the challenges of flooding through improving decision-making process for minimizing the flood hazards in the study area. Specific objectives are to assess the land use /land cover changes, rainfall variability as well as potential for flood incidence in the study area, using available records of data. Main hypothesis is that the increase in the built-up area, poor drainage, non-compliance to government regulation and indiscriminate waste disposal exacerbate flooding in the study area. This study is expected to contribute to informed implementation of policies relating to climate change adaptation and mitigation in the area.

\subsection{Material and Method}

\subsection{Study Area}

Isheri North is located at the outskirt of Lagos, sharing ground with Ogun State. It is located approximately between the latitude $6^{\circ} 64^{\prime} \mathrm{N}$ and longitude $3^{\circ} 40^{\prime} \mathrm{E}$. The climate is that of the tropical rainforest zone in Nigeria, with mean annual rainfall of about $1015.09 \mathrm{~m}$ and annual maximum temperature between $28^{\circ} \mathrm{C}$ to $32^{\circ} \mathrm{C}$ (Ufoegbune, et al, 2011) (Figure 1). The tropical rain forest area are characterized by long wet season spanning from April to October and short dry season spanning from November to March (Adeoti, et al, 2015) . The 
topography is relatively flat with elevation differential over a long distance as River Ogun (Oyegoke and Sojobi, 2012). The total traversing and forming the boundary with the Isheri North scheme is over $4000 \mathrm{~m}$. The river is about $100 \mathrm{~m}$ wide, and between $3 \mathrm{~m}$ and $6 \mathrm{~m}$ deep at this reach. The flow of the Ogun river is influenced by heavy and intense throughout the lower course of the river especially in the Ogun-Lagos section, release of water from the over flowing Oyan dams upstream and the high tides of the Lagos Lagoon (Aketoyon et al, 2010).

It consists of both residential and commercial plots to assist in resolving the ever-increasing overpopulation, uncoordinated settlement patterns and socio-economic growth associated with the emerging Lagos mega-city.

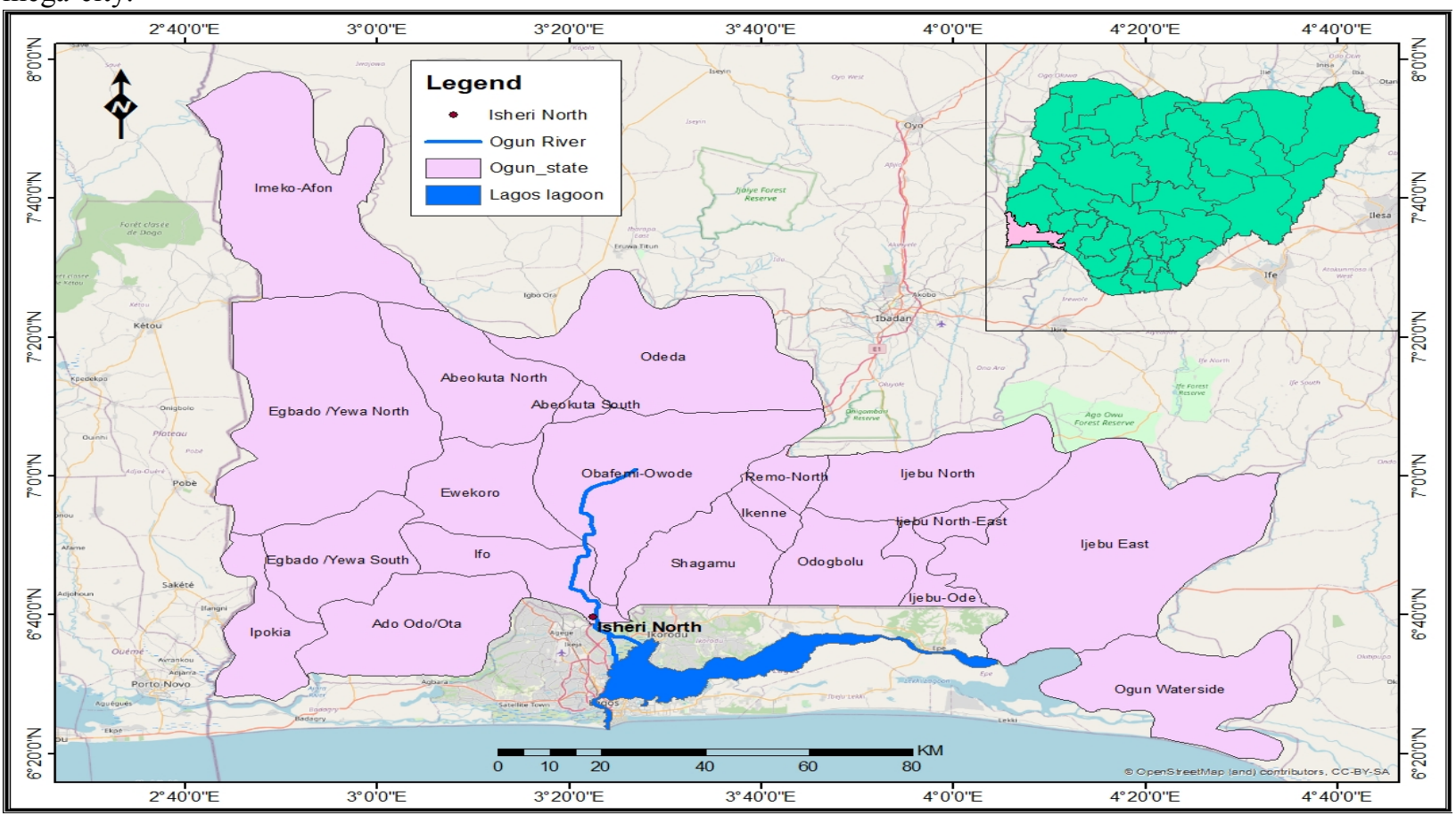

Figure 1: The study area, Isheri North in Ogun State, Nigeria.

\subsection{Data collection}

Monthly rainfall dataset for 30 (1990-2019) years for the study area was acquired from the archive of Nigerian Meteorological Agency's station at Ikeja, Lagos State, with Land sat images (2000, 2015 and 2020) covered the study area. Landsat imageries were preferred in this study because of the availability of the Landsat imageries at different time within the study period, unlike other available image sensors, including SPOT and MODIS, which do not have similar temporal coverage. Landsat is also a frequently used remotely sensed data source across the sub-Saharan Africa because it is freely available (Eludoyin et al, 2019; Eludoyin and Iyanda, 2019), technically suitable and readily available (Chander et al., 2009).

The choice of years $(2000,2015$ and 2020) covered was informed by data availability, quality and the need for a relatively long time lag for noticeable change in the study area. Landsat imageries, based on their specific characteristics (Table 1) were downloaded from the archive of the United States' Geological Surveys as described in Eludoyin and Iyanda (2019). Useful information about the flooding phenomenon in the area was derived from books, journals, online databases and newspapers report.

Table 1. Details of the satellite data used in the study.

\begin{tabular}{lllll}
\hline Satellite sensor & Path/Row & Date acquired & $\begin{array}{l}\text { Land use/ land cover } \\
\text { map naming }\end{array}$ & $\begin{array}{l}\text { Spatial resolution } \\
\text { meters) }\end{array}$ \\
\hline Landsat ETM+ & $191 / 55$ & $06 / 10 / 2000$ & LULC 2000 & 30 \\
\hline Landsat ETM+ & $191 / 55$ & $10 / 12 / 2015$ & LULC 2015 & 30 \\
\hline Landsat OLI TIRS & $191 / 55$ & $10 / 01 / 2020$ & LULC 2020 & 30 \\
\hline
\end{tabular}

\subsection{Data analysis}

Rainfall data were analyzed for mean monthly, annual and long term mean trend and variability while the Landsat imageries were first corrected for line striping and later enhanced in remote sensing software (ENVI 4.5). Further correction of geometric and radiometric errors was achieved using ArcGIS software (version 10.5). After geo-referencing, study area was clipped out of the entire image scene using the 'Spatial Analyst' tool in ArcGIS, and then subjected to supervised classification. To achieve supervised classification, spectral signatures were 
obtained from specified locations (training areas) in the study area and linked with their appearance on the imageries. Supervised signature extraction with the maximum likelihood classification algorithm was used to classify the different training samples of the images of the study area as five land use classes were classified, following a modification of Anderson et al. (1976)'s recommendation. For this study, the identified land use/cover includes water body, vegetation, sandbar, built-up and wetlands. The Kappa coefficients of the supervised classification for of the selected years were at least 0.90 , indicating strong agreement between the classified pixels and the field objects (Zeng et al, 2015). Consequently, the classified imageries considered to be of desired quality for interpretation in this study. Figure 2 present the flowchart for the land use/land cover and change detection analysis in the study

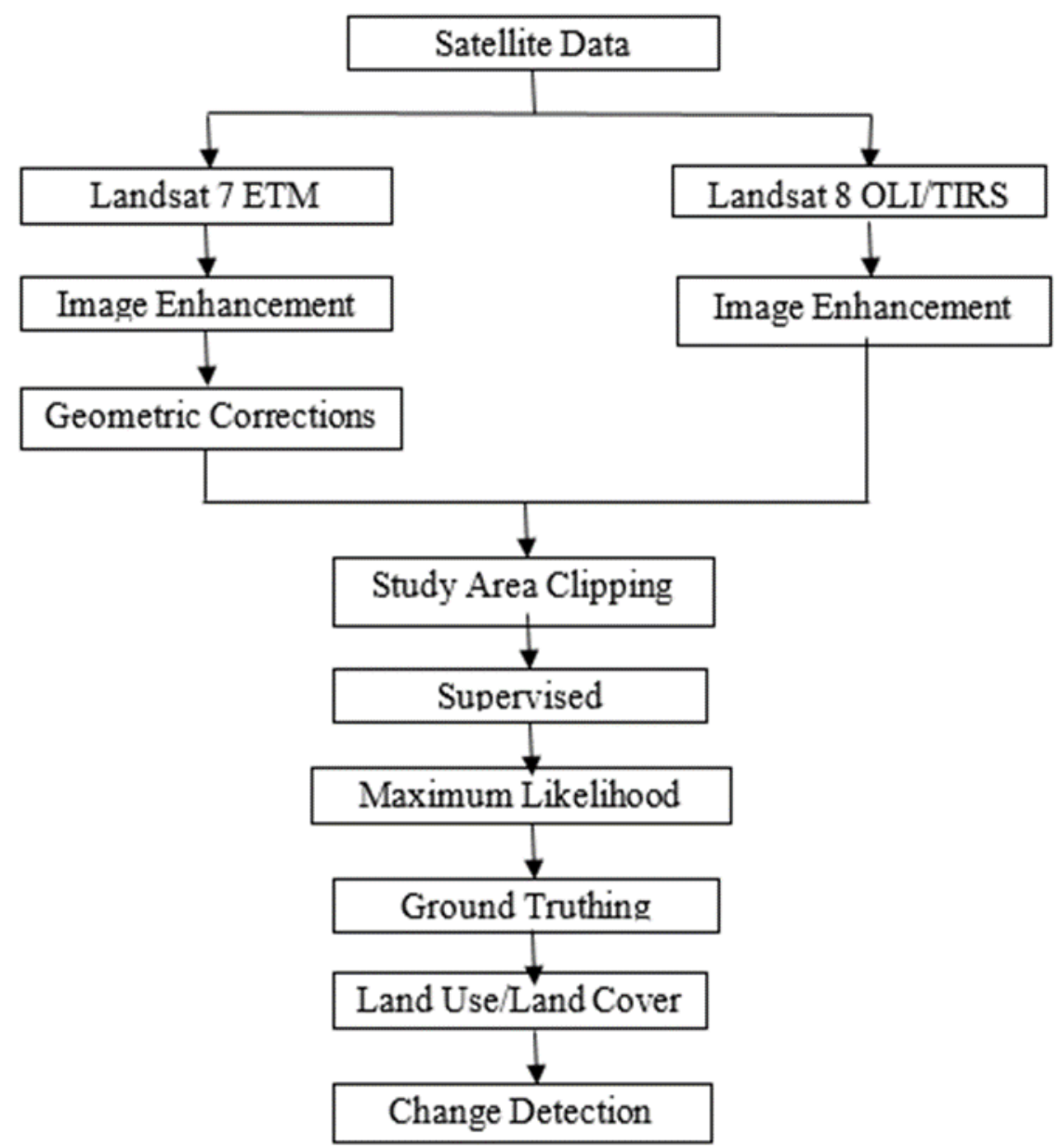

Figure 2:Flowchart of the land use/land cover and change detection analysis of the study area.

\subsection{Result}

\subsection{Rainfall Pattern}

The study area is located within the tropical rainforest region, is characterized by distinct wet and dry seasons. The analysis of rainfall data which spanned a period of 30 years, shows the trend of the amount rainfall received in the study. There has been some consistency in the rainfall pattern with slight variations. In Figure 3 below, it can be seen that over the years, Isheri North has experienced a steady rise in annual rainfall, with a usual decrease between December and January. The mean monthly rainfall is $130.2 \mathrm{~mm}$ while the mean annual rainfall is $132.6 \mathrm{~mm}$.

In Figure 3 and 4 below, it can be seen that over the years, Isheri North has experienced a steady rise in annual rainfall decrease between December and January. Therefore, the statistical technique test was done using regression analysis to help show whether there is any significant relationship between rainfall and flooding in the study area. (As shown in figure 4). 


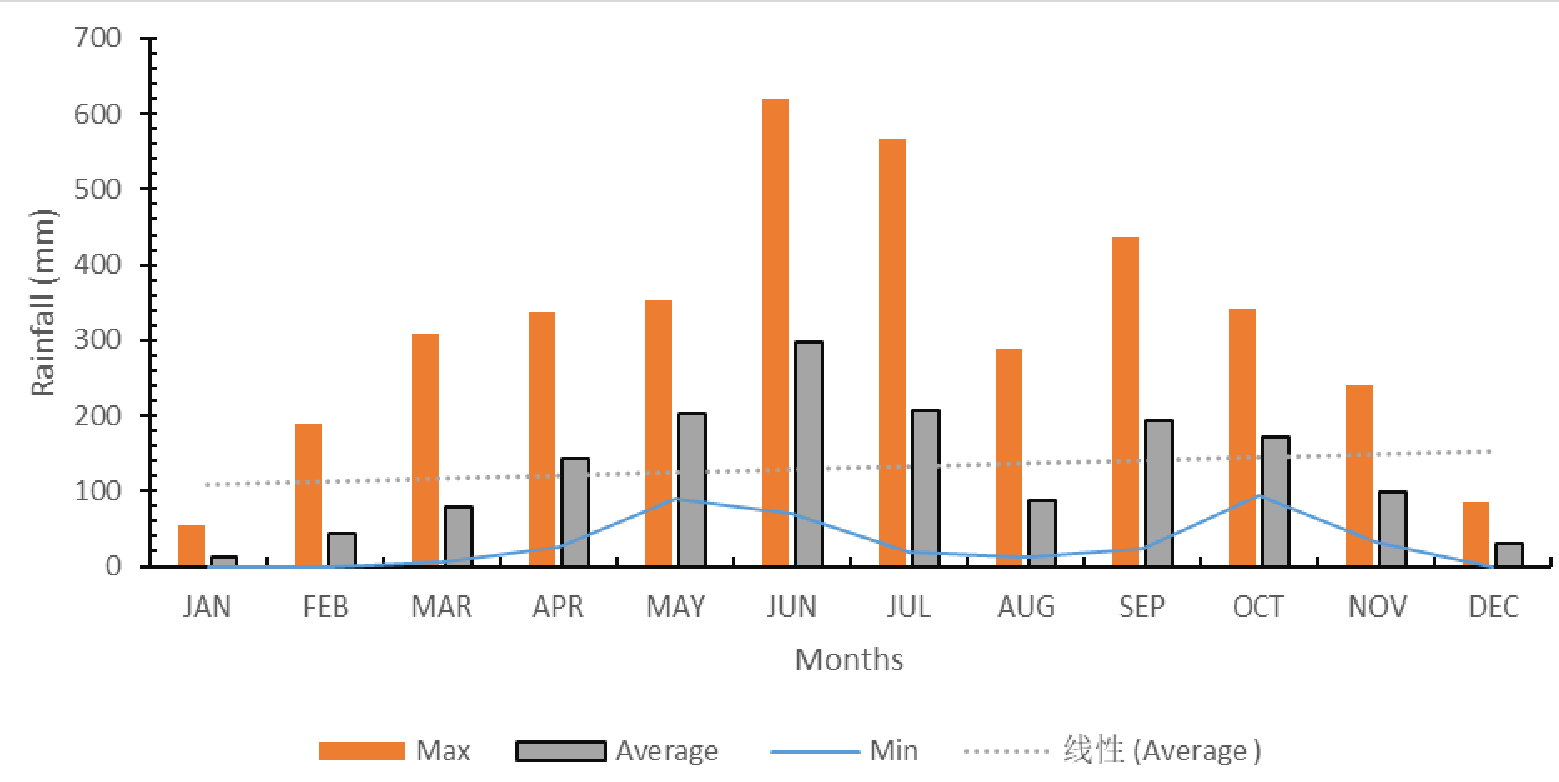

Figure 3: Change and trend in mean monthly Rainfall pattern over Isheri North between 1990 and 2019

The result of linear regression analysis conducted on the annual mean rainfall indicates a slight increase over the years $(b=0.7, \mathrm{R} 2=0.6)$, although a cursory look at the annual pattern shows a relatively more rainfall in 2004, 2009 and 2016 than the other years (Figure 4). An evaluation of flood pattern over the study area indicates that flooding events occur, during both intense and slight rainfall, suggesting the dominance of infiltration excess-runoff during non-intense rainfall or saturation-excess runoff in the period of intense rainfall. The study area is hugely covered by impervious surfaces, largely due concretization of the land surface and the high densities of structures in the study area (Gholami et al., 2010). Also, poor urban planning waste management have been linked to flood events that are induced by blockage of river channels.

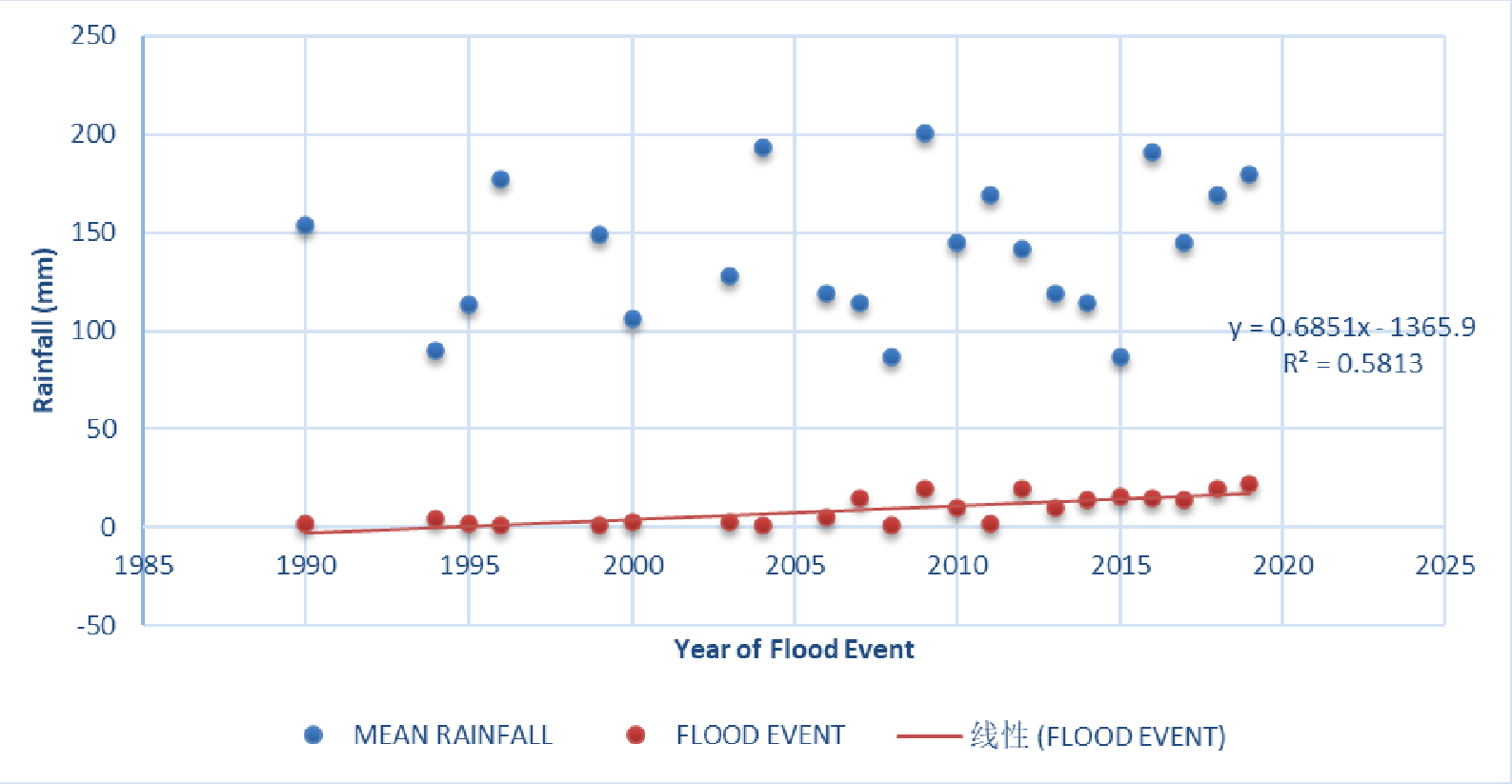

Figure 4: Relationship between rainfall and flood Event in the study area.

\subsection{Trend of Land use and Land cover change}

The result of the LU/LC reveals the change in the vegetation cover (the green), water bodies (the blue) and other features as depicted on their respective legend. A summary from the classified images was listed in Table 2 and illustrated in Figure 5 for easy interpretation.

Figure 5 shows that there exists a change in each of the Land Use/Land Cover categories considered in this study (explicitly Water Bodies, Vegetation, Bare Surface and Built-up Area). Vegetation which formed a resistive feature against the flood had decreased from $183.9 \mathrm{~km} 2$ in 2000 to $128.0 \mathrm{~km} 2$ in 2020 which was due to 
increase in population thus necessitating the construction of infrastructure facilities. The portion within the study area that reflected the influence of human activities (such as; anthropogenic activities) is denoted as Built-up Area. The Built-up Area covered $62.4285 \mathrm{~km} 2$ of the study area which was $7.6 \%$ of the whole spatial extent in 2000 , but had increased to $14.97 \%$ that was $83.2374 \mathrm{~km} 2$ in the year 2015 and by the year $2020,24.52 \%$ the increment was recorded for Built-up area.

Table 2 Change in land use /land cover in study area selected Imageries

\begin{tabular}{|l|l|l|l|l|}
\hline $\begin{array}{l}\text { Land Use/Land } \\
\text { Cover }\end{array}$ & $\begin{array}{l}\mathbf{2 0 0 0} \\
\left.\text { Area } \mathbf{( k m}^{\mathbf{2}}\right)\end{array}$ & $\begin{array}{l}\mathbf{2 0 1 5} \\
\left.\text { Area } \mathbf{( k m}^{\mathbf{2}}\right)\end{array}$ & $\begin{array}{l}\mathbf{2 0 2 0} \\
\left.\text { Area } \mathbf{( k m}^{\mathbf{2}}\right)\end{array}$ & $\begin{array}{l}\text { Change Between 2000 } \\
\text { and 2015 }\end{array}$ \\
\hline Water body
\end{tabular}

From (Table 1 and Figure 7), of the study area, It can be seen that most of these Built-ups are situated in the area associated with a high elevation and along the roadsides that had already been sand-filled during road construction activities. The major bare surface feature in the study area as confirmed via ground-truthing was white sands. This development occurred when the water had been drained due to the increase in evaporation rate and sand filling of the area for construction purposes. From the land use classification carried out i.e Figure 6, it is clear that most residential and commercial building in study area are constructed on floodplain. Also most of the roads constructed have no drainage channels for the flow of water and when there is rainfall in the area. The few drainage channels available are blocked as a result of poor drainage which ultimately disrupt the flow of water thereby resulting in a high flood in the area of study. The incidence of floods in the study area of Isheri North was caused by a combination of natural and human-induced activities along the floodplains. Isheri North happens to be a flood plain making it to be vulnerable to flooding, coupled with increasingly growing human activities like building, dumping of refuge on the waterways, and excavation of sand along the riverbank increase the risk of flood disasters.

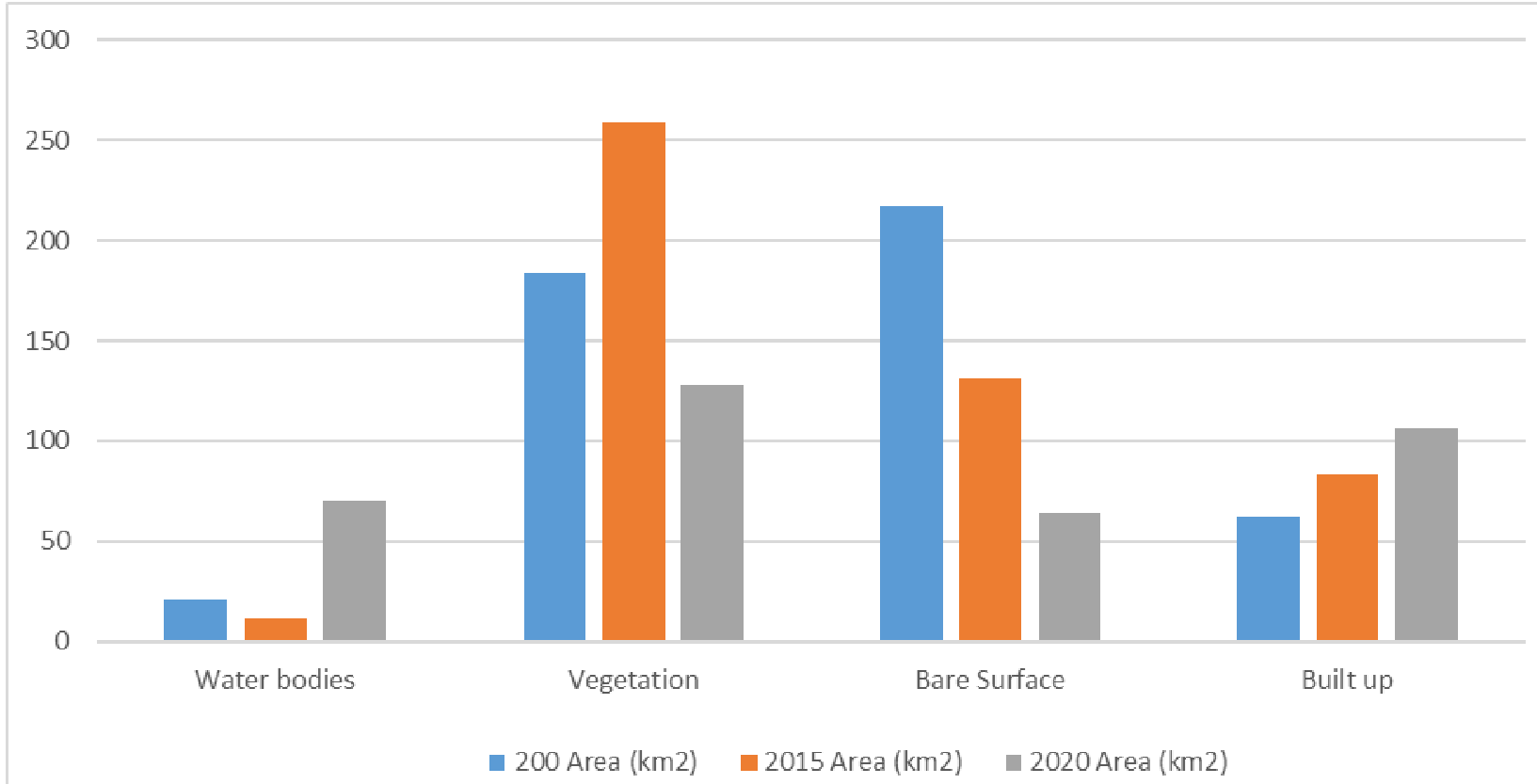

Figure 6: Variations in land use/cover for the study area over the study period 

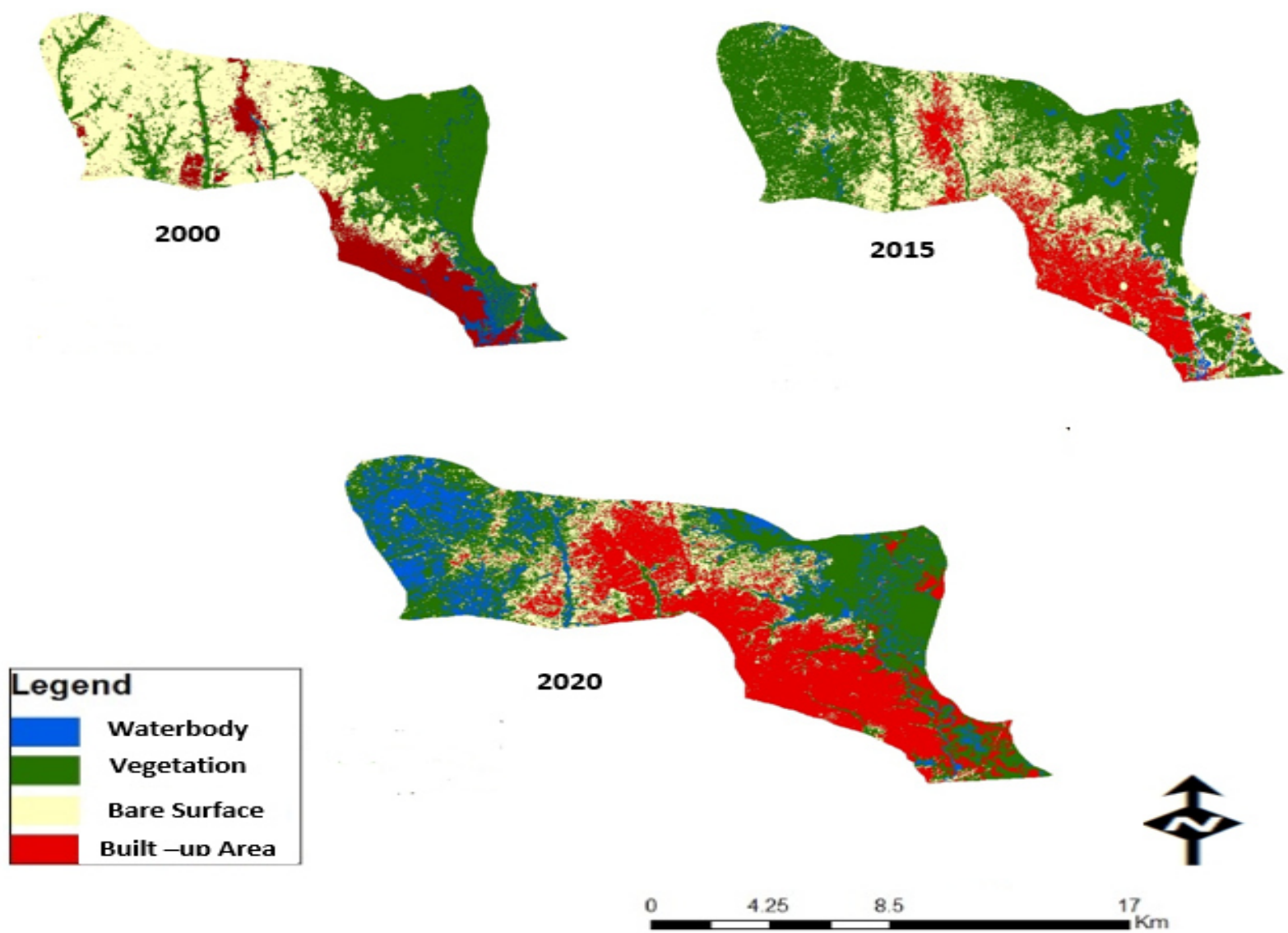

Figure 7: Classified land use/land cover image over study area for the year $2000-2020$

From the land use classification carried out (Figure 7), the trend of changes in the study area indicated an increase in built-up areas/impervious surfaces. Therefore, it can be seen that apart from climatic factors attributed the cause of flood in the study area; socioeconomic factors are also implicated, rapid urbanisation that dominated the study area (Offia, 2011), increase severity of the flood and land use associated with the trend in the study area as observed by Adelekan (2010) rising water levels leading to flooding are associated with poorly managed urbanization. Plate 2, shows the pictorial poorly drainage system in the study area as a result of continued dumping of waste in the floodplain with little or no drainage channels which disrupt the flow of water thereby resulting in a high flood in the area of study.

Thus, apart from climatic factors attributed to the cause of flood in the study area; socioeconomic factors are also critical in the increasing impact of the flood in the area. These include rapid population growth of the study area (Oduwaye, 2013). These are corroborated by Adelekan (2010). The latter author observed that the rise in water level always leads to flood in the study area and is caused by urbanization and poorly little or no drainage systems.

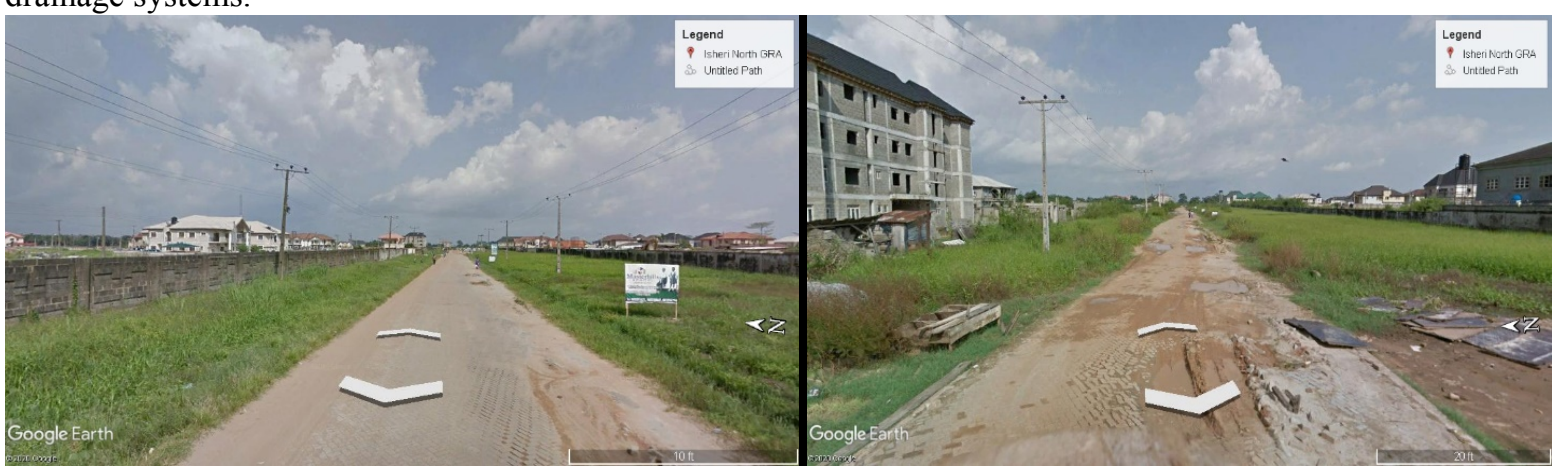

Plate 2: Poorly drainage system in the study area.

\subsection{Conclusion and recommendations}

This study revealed the change in Land use/ Land cover, during this period from 2000 to 2020 with the combined approach of remotely sense GIS, and rainfall dataset. To conduct the study a rainfall dataset for 30 
years 1990 to 2019 were obtained from the archived of Nigeria Meteorological Agency Ikeja station and analyzed using simple statistical technique to assess the characteristic that could lead to the flood event and a supervised maximum likelihood classification methods were used to produce Land use/Land cover maps by using Landsat ETM+/OLI satellite images of 2000, 2015 and 2020. The rainfall dataset and geographical information system (GIS) approaches helps us to identify the factors causing flooding in the study area, such as climatic variability, rapid population growth, the poor drainage system and real estate development. The study shows that rainfall dataset and GIS which indicated the flood-prone risk and vulnerability of the settlement and infrastructures are the effective and efficient tools in the study and mapping of flooding in Isheri north. The challenges of flooding in the Isheri- north area of Lagos Nigeria are significant issues within the context of environmental management and sustainable development. Available records indicate that flooding in the area affects the human population, destroys public assets and disrupts economic activities.

Unfortunately, these incidences of flooding in Isheri North are not disappearing and are even likely to get worse due to climate change. Growing population increases which is putting pressure on housing is exacerbating the challenges. However, this can be tamed by controlling - , proper urban planning and proper environmental regulations on real estates, raising of public awareness and sensitization on the real dangers of encroaching floodplains by civic society to initiate and encourage community participation in flood prevention, control and mitigation. Dredging operation should be carried out to allow the river flow freely through its natural channel. Also, there should be a comprehensive mapping of the flood plains beyond the study area for proper planning, awareness and enlightenment. Finally, government, private and non-government organization that are involved in flood monitoring and management should imbibe the use of GIS for data generation and decision makings, if there can be a considerable reduction in its impacts. The flooding within Isheri North Scheme could be avoided if a preliminary assessment study, evaluation and practicability of implementing Isheri North Scheme on the floodplain of such important river as River Ogun had been done.

\section{References}

Adewumi, J. R., Akomolafe, J. K., Ajibade, F. O. and Fabeku, B. B. (2016). Application of GIS and Remote Sensing Technique to Change Detection in Land Use/Land Cover Mapping in Igbokoda, Nigeria. Journal of Applied Science and Process Engineering (JASPE), Unimas, Malaysia, Volume 3, No. 1. Pages $34-54$

Okoye, C. B., \& Ojeh, V. N. (2015). Mapping of flood prone areas in Surulere, Lagos, Nigeria: a GIS approach. Journal of Geographic Information System, 7(02), 158. Olayinka, D. N., Nwilo, P. C., \& Emmanuel, A. (2013). From Catchment to Reach: Predictive Modelling of Floods in Nigeria. Proceedings of the FIG Working Week, Environment for Sustainability, Abuja, Nigeria, 6-10.

Levermann, A., Clark, P. U., Marzeion, B., Milne, G. A., Pollard, D., Radic, V., \& Robinson, A. (2013). The multimillennial sea-level commitment of global warming. Proceedings of the National Academy of Sciences, 110(34), 13745-13750.Smith (1996)

Oyinloye, M., Olamiju, I., \& Adekemi, O. (2013). Environmental impact of flooding on Kosofe local government area of Lagos state, Nigeria: a GIS perspective. Journal of Environment and Earth Science, 3(5), 57-66.

Times, S. (1988). April 6, 1997. 30 Fortune.

Ojeh, V. N., \& Ugboma, P. (2012). Flood hazards in urban Niger delta: A case study of Abraka Town. International Journal of Environmental Engineering Research, 1(1), 23-29.

Amoako, C. (2012). Emerging issues in urban flooding in African cities-The Case of Accra, Ghana. In 35th AFSAAP annual conference proceedings. Nkeki, F. N., Henah, P. J., \& Ojeh, V. N. (2013). Geospatial techniques for the assessment and analysis of flood risk along the Niger-Benue Basin in Nigeria.

Onwuka, S., Ikekpeazu, F. O., \& Onuoha, D. (2015). Assessment of the causes of 2012 floods in Aguleri and Umuler, Anambra East local government area of anambra sstate, Nigeria. British Journal of Environmental Sciences, 541, 43-57.

Eruola, A. O., Ufoegbune, G. C., Awomeso, J. A., \& Abhulimen, S. A. (2011). Assessment of cadmium, lead and iron in hand dug wells of Ilaro and Aiyetoro, Ogun State, South-Western Nigeria. Research Journal of Chemical Sciences

Oyegoke, S. O., \& Sojobi, A. O. (2012). Developing appropriate techniques to alleviate the Ogun River network annual flooding problems. International Journal of Scientific \& Engineering Research, 3(2), 1-7.

Adeoti, L., Bello, M. A., Olatinsu, O. B., \& Adiat, K. A. N. (2015). Application of geoelectrical and chemical methods for groundwater assessment in Isheri-North, Ogun state, Nigeria. Journal of Science and Technology (Ghana), 35(1), 24-38.

Aketoyon, I. S., Ogundele, F. O., \& Soladoye, O. (2010). Characterization by factor analysis of chemical faces of groundwater in the coastal plain sands aquifer of Lagos, South Western Nigeria. Int'l J. of Academic Research, 2(5).

Toka S.O, (2017) Technique of GIS in Assessment of Flood Hazards in Eti-Osa, Lagos, Nigeria. Academia edu. 
Idris, S., \& Dharmasiri, L. M. (2015). Urban development and the increasing trend of flood risk in Gombe metropolis, Nigeria. International Journal of Science and Research, 5(8), 500-504.

Oduwaye, L. (2013). Urban planning implications of changing land use structure of metropolitan Lagos, Nigeria. Proceedings of the Real Corp Tagungsband Planning Times, 1055-1065.

Adelekan, I. O. (2010). Vulnerability of poor urban coastal communities to flooding in Lagos, Nigeria. Environment and urbanization, 22(2), 433-450.

Yoade, A. O., Onifade, V. A., \& Olajide, T. P (2014). An assessment of public perception of flooding in Akure, Nigeria. 